\title{
ПРОБЛЕМИ І ПЕРСПЕКТИВИ ВИКЛАДАННЯ «ОСНОВ МЕДСЕСТРИНСТВА» В ЧЕРКАСЬКОМУ БАЗОВОМУ ДЕРЖАВНОМУ МЕДИЧНОМУ КОЛЕДЖІ
}

\author{
Н. В. Зарудняк, Н. І. Рега, І. Я. Господарський \\ ДВНз «Тернопільський державний медичний університет \\ імені І. Я. Горбачевського МОЗ Украӥни" \\ Черкаський базовий державний медичний коледж
}

У статті проаналізовано рівень знань з предмета «Основи медсестринства» за результатами тестування студентів різних курсів та випускників Черкаського базового державного медичного коледжу 3 метою оцінки якості їх навчання та розробки подальших рекомендацій для підвищення ефективності викладання предмета «Основи медсестринства».

\section{PROBLEMS AND PERSPECTIVES OF TEACHING OF SUBJECT «FUNDAMENTALS OF NURSING» IN CHERKASY BASIC STATE MEDICAL COLLEGE}

\author{
N. V. Zarudnyak, N. I. Rega, I. Ya. Hospodarskyy \\ I. Horbachevsky Ternopil State Medical University \\ Cherkasy Basic State Medical College
}

\begin{abstract}
The article presents the analysis of level of knowledges on the subject «Fundamentals of Nursing» based on the results of the testing of students of different courses and postgraduates of the Cherkassy Basic State Medical College. The aim of investigation is to assess the quality of students education and develop further recommendations for improving teaching effectiveness of subject «Fundamentals of Nursing».
\end{abstract}

Вступ. У процесі формування медсестринська справа постійно зазнавала багатьох змін та удосконалень, проте була спільна мета - допомогти хворій людині нормалізувати фізичний і психічний стани, тобто відновити здоров'я пацієнта, створити оптимальні умови для його збереження.

Загальною метою вивчення предмета «Основи медсестринства» $є$ засвоєння студентами теоретичних знань та практичних умінь при здійсненні основних етапів медсестринського процесу. Формування власного погляду на професію, ознайомлення з моральними концепціями, принципами й традиціями медсестринської справи дасть змогу студентам краще зрозуміти сутність майбутньої професії.

Сучасні дослідники медсестринства у власних теоріях звертають особливу увагу на те, що медична сестра повинна допомагати пацієнту самостійно вирішувати проблеми, що виникли в результаті хвороби, навчити

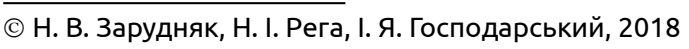

його відновлювати здоров'я та вміти зберігати його у майбутньому, тобто чільне місце в роботі медичної сестри відводять саме медсестринській педагогіці [1].

За мету процесу навчання поставлено особисте створення пацієнтом власного комфорту та умов для збереження чи відновлення здоров'я. Позитивні результати навчання дають змогу медичній сестрі зменшити обсяг втручань на даного пацієнта, й збільшити час для догляду за тяжкохворими пацієнтами, які потребують більшого догляду.

Процес навчання розповсюджується й на членів родини пацієнта в разі неможливості самостійно доглядати за собою протягом тривалого часу [2].

Тому однією з основних функцій медичної сестри, за визначенням Європейського регіонального бюро ВОО3, є навчання пацієнтів збереження та відновлення здоров'я шляхом:

- оцінки знань і навичок людини, що стосуються збереження і відновлення здоров'я; 
- підготовки і надання необхідної інформації на відповідному рівні;

- надання допомоги медичним сестрам, пацієнтам та іншому персоналу в отриманні нових знань і навичок;

- застосування прийнятих професійних стандартів навчання пацієнтів та членів їх родини [1].

Медсестринський процес повинен виховати у студентів - майбутніх медичних сестер здатність до чіткого розуміння проблем пацієнта і самостійного прийняття рішень у межах своєї компетенції.

Тому предмет «Основи медсестринства» розглядають як базовий у формуванні фахового світогляду сучасної медичної сестри, яка володіє мистецтвом спілкування та медсестринською педагогікою, методологією встановлення медсестринського діагнозу, здійснює медсестринський процес одночасно за кількома моделями з тим, щоб якомога повніше задовольнити потреби пацієнта [3, 4]. Це, в свою чергу, створює наукову базу для подальшого вивчення клінічного медсестринства та формування у майбутнього фахівця цілісного (холістичного) бачення пацієнта.

Мета дослідження: проаналізувати рівень знань 3 предмета «Основи медсестринства» за результатами тестування студентів та випускників Черкаського базового державного медичного коледжу з метою оцінки якості їх навчання та розробки подальших рекомендацій для підвищення ефективності викладання предмета «Основи медсестринства».

Основна частина. Дослідження провели на базі Черкаського базового державного медичного коледжу протягом 2016-2017 рр. У ньому брали участь студенти різних курсів та різних спеціальностей та випускники, які навчалися на курсах післядипломної освіти.

Ми провели тестування 30 медичних сестер II курсу, 40 медичних сестер IV курсу та 25 працюючих медичних сестер - випускників Черкаського базового державного медичного коледжу, які навчались на курсах підвищення кваліфікації і мали стаж роботи більше 5 років.

Для визначення рівня знань студентів та випускників коледжу створили буклет із 50 тестових завдань множинного вибору, які належали до основних розділів предмета «Основи медсестринства», зокрема:

- «Медсестринський процес» - 10 запитань;

- «Санітарно-протиепідемічний режим» - 10 запитань;

- «Виписування, зберігання та застосування лікарських засобів» - 10 запитань;

- «Спостереження за пацієнтами» - 15 запитань;

- «Найпростіші методи фізіотерапії» - 5 запитань.

Ми провели тестування 30 медичних сестер II курсу з предмета «Основи медсестринства» (табл. 1, рис. 1). Як видно з рисунка 1, найнижчими були знання студентів - медичних сестер II курсу з розділів «Санітарно-протиепідемічний режим» та «Найпростіші методи фізіотерапії». Відповідно, найкраще студенти знали розділи «Медсестринський процес» та «Виписування, зберігання та застосування лікарських засобів».

Також ми провели тестування 40 медичних сестер IV курсу з предмета «Основи медсестринства» (табл. 2, рис. 2).

Як видно із рисунка 2, найнижчими були знання студентів - медичних сестер IV курсу з розділів «Санітарно-протиепідемічний режим» та «Найпростіші методи фізіотерапії». Відповідно, найкраще студенти знали розділи «Медсестринський процес» та «Виписування, зберігання та застосування лікарських засобів».

I нарешті, ми проведели тестування 25 працюючих медичних сестер, які навчались на післядипломній освіті, з предмета «Основи медсестринства» (табл. 3, рис. 3).

Цікавим був той факт, що тільки 5 медичних сестер (відповідно 20 \% від усіх респондентів), які навчались на післядипломній освіті, зробили помилки у тестових завданнях із розділу «Медсестринський процес».

Як видно із рисунка 3, найнижчими були знання студентів - медичних сестер, які навчались на післядипломній освіті, з розділів «Санітарно-протиепідемічний режим», «Виписування, зберігання та застосування лікарських засобів» та «Спостереження за пацієнтами». Відповідно, найкраще студенти знали розділи «Медсестринський процес» та «Найпростіші методи фізіотерапії».

Таблиця 1. Кількість помилок у тестах медичних сестер II курсу відповідно до розділів

\begin{tabular}{|l|c|c|c|c|c|}
\hline \multicolumn{1}{|c|}{ Розділ } & $\begin{array}{c}\text { Медсестринський } \\
\text { процес }\end{array}$ & $\begin{array}{c}\text { Санітарно- про- } \\
\text { тиепідемічний } \\
\text { режим }\end{array}$ & $\begin{array}{c}\text { Виписування, 3бері- } \\
\text { гання, застосування } \\
\text { лікарських засобів }\end{array}$ & $\begin{array}{c}\text { Спостереження } \\
\text { за пацієнтами }\end{array}$ & $\begin{array}{c}\text { Найпростіші } \\
\text { методи } \\
\text { фізіотерапії }\end{array}$ \\
\hline Кількість ТЗ (n) & 300 & 300 & 300 & 450 & 150 \\
\hline Кількість помилок & 36 & 69 & 46 & 84 & 30 \\
\hline Відносний показник (\%) & 12 & 23 & 15,3 & 18,6 & 20 \\
\hline
\end{tabular}




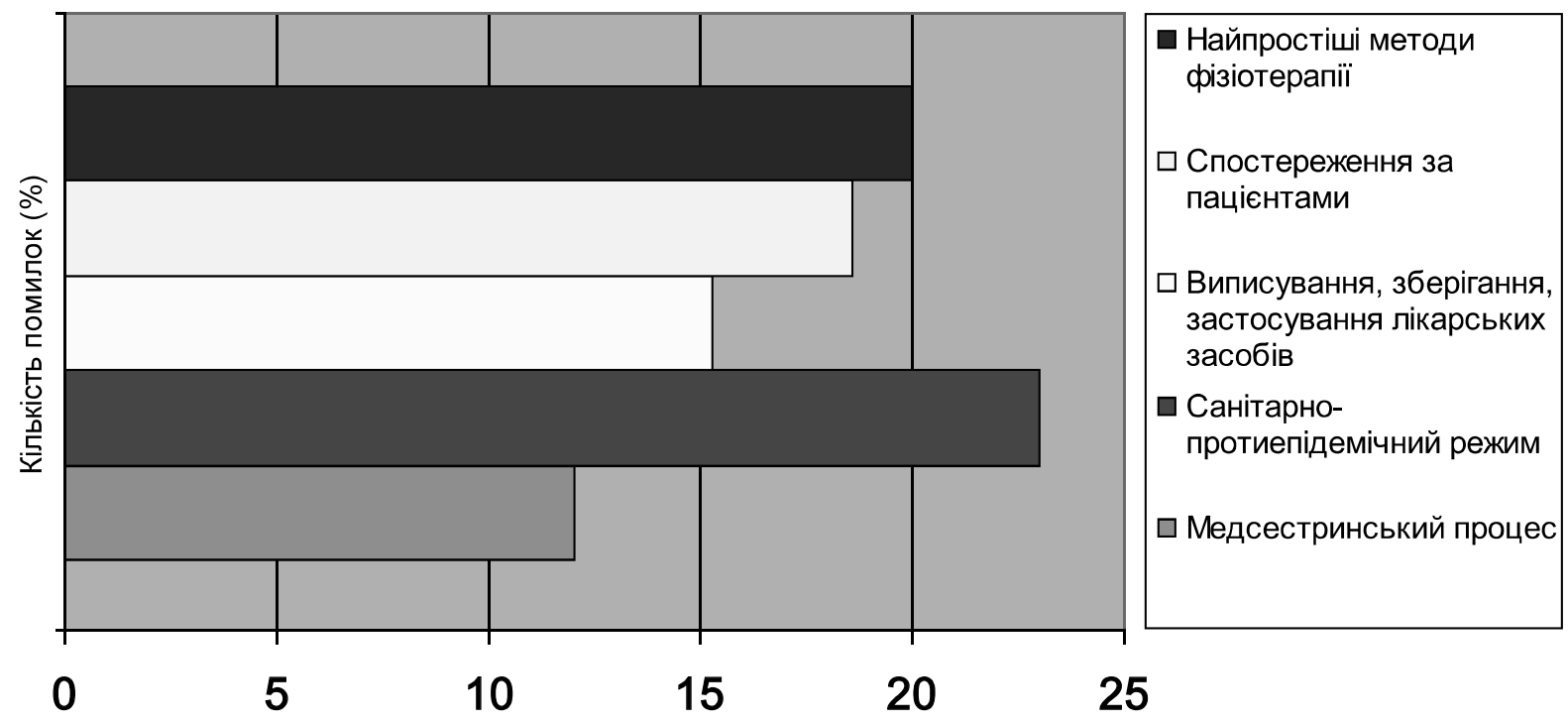

Рис. 1. Кількість помилок у тестах медичних сестер II курсу відповідно до розділів.

Таблиця 2. Кількість помилок у тестах медичних сестер IV курсу відповідно до розділів

\begin{tabular}{|l|c|c|c|c|c|}
\hline \multicolumn{1}{|c|}{ Розділ } & $\begin{array}{c}\text { Медсестрин- } \\
\text { ський процес }\end{array}$ & $\begin{array}{c}\text { Санітарно- } \\
\text { протиепідемічний } \\
\text { режим }\end{array}$ & $\begin{array}{c}\text { Виписування, } \\
\text { зберігання, } \\
\text { застосування } \\
\text { лікарських засобів }\end{array}$ & $\begin{array}{c}\text { Спостереження } \\
\text { за пацієнтами }\end{array}$ & $\begin{array}{c}\text { Найпростіші } \\
\text { методи } \\
\text { фізіотерапії }\end{array}$ \\
\hline Кількість Т3 (n) & 400 & 400 & 400 & 600 & 200 \\
\hline Кількість помилок & 60 & 112 & 79 & 129 & 55 \\
\hline $\begin{array}{l}\text { Відносний } \\
\text { показник (\%) }\end{array}$ & 15 & 28 & 19,7 & 21,5 & 27,5 \\
\hline
\end{tabular}

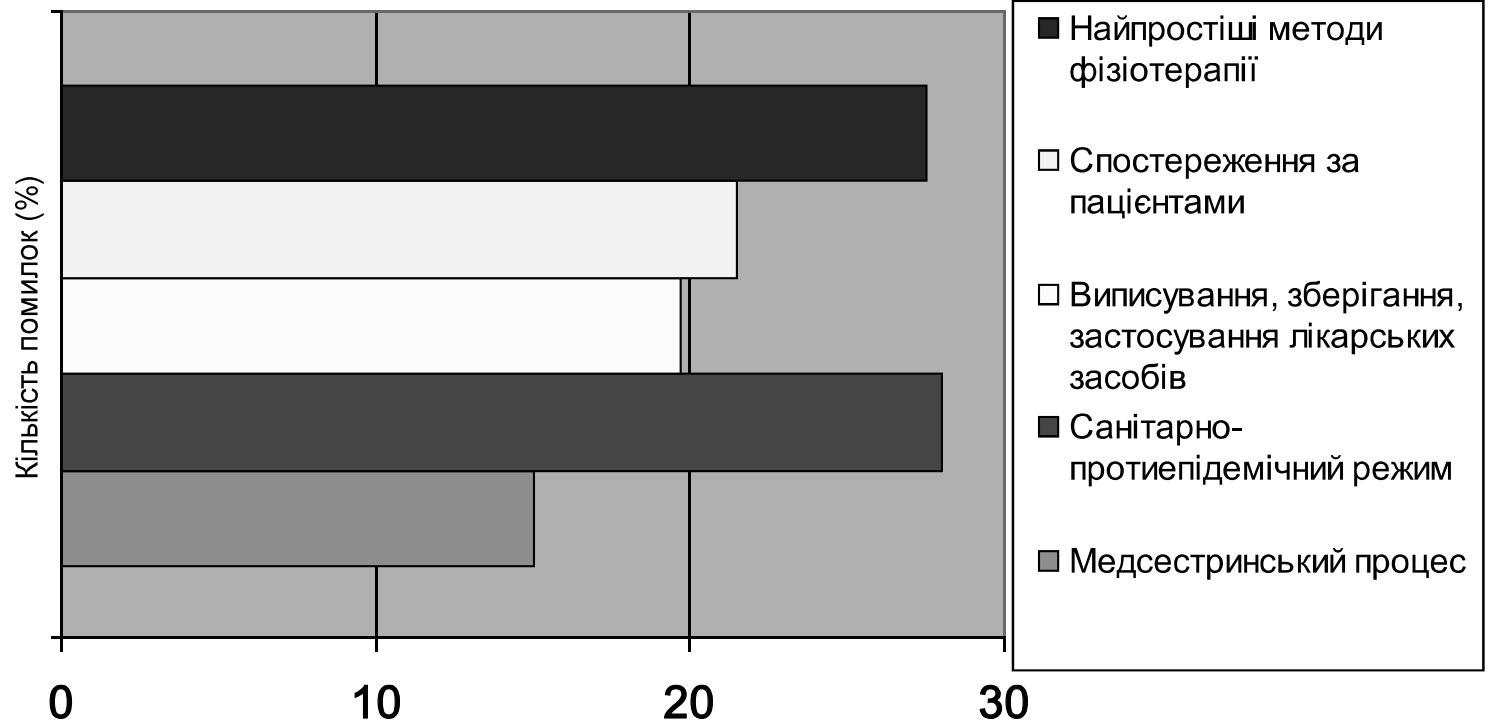

Рuc. 2. Кількість помилок у тестах медичних сестер IV курсу відповідно до розділів.

Ми запропонували шляхи покращення викладання «Основ медсестринства», які дадуть змогу підвищити якість навчання і рівень знань студентів.

У сучасній медицині велику роль відіграє медична сестра. В зв'язку з реформуванням сестринської освіти на Україні та переходом від медичної моделі підготовки сестер до медсестринської передбачено створення спеціаліста якісно нового рівня професіоналізму, якому властива професійна компетентність, вміння контролювати ситуацію, самостійно і 
Таблиця 3. Кількість помилок у тестах працюючих медичних сестер відповідно до розділів

\begin{tabular}{|c|c|c|c|c|c|}
\hline Розділ & $\begin{array}{c}\text { Медсестрин- } \\
\text { ський процес }\end{array}$ & $\begin{array}{c}\text { Санітарно- } \\
\text { протиепідемічний } \\
\text { режим }\end{array}$ & $\begin{array}{c}\text { Виписування, } \\
\text { зберігання, засто- } \\
\text { сування лікарських } \\
\text { засобів }\end{array}$ & $\begin{array}{c}\text { Спостереження } \\
\text { за пацієнтами }\end{array}$ & $\begin{array}{c}\text { Найпростіші } \\
\text { методи } \\
\text { фізіотерапії }\end{array}$ \\
\hline Кількість Т3 (n) & 250 & 250 & 250 & 375 & 125 \\
\hline $\begin{array}{c}\text { Кількість } \\
\text { помилок }\end{array}$ & 16 & 77 & 63 & 93 & 55 \\
\hline $\begin{array}{c}\text { Відносний } \\
\text { показник (\%) }\end{array}$ & 6,4 & 30,8 & 25,2 & 24,8 & 4,4 \\
\hline
\end{tabular}

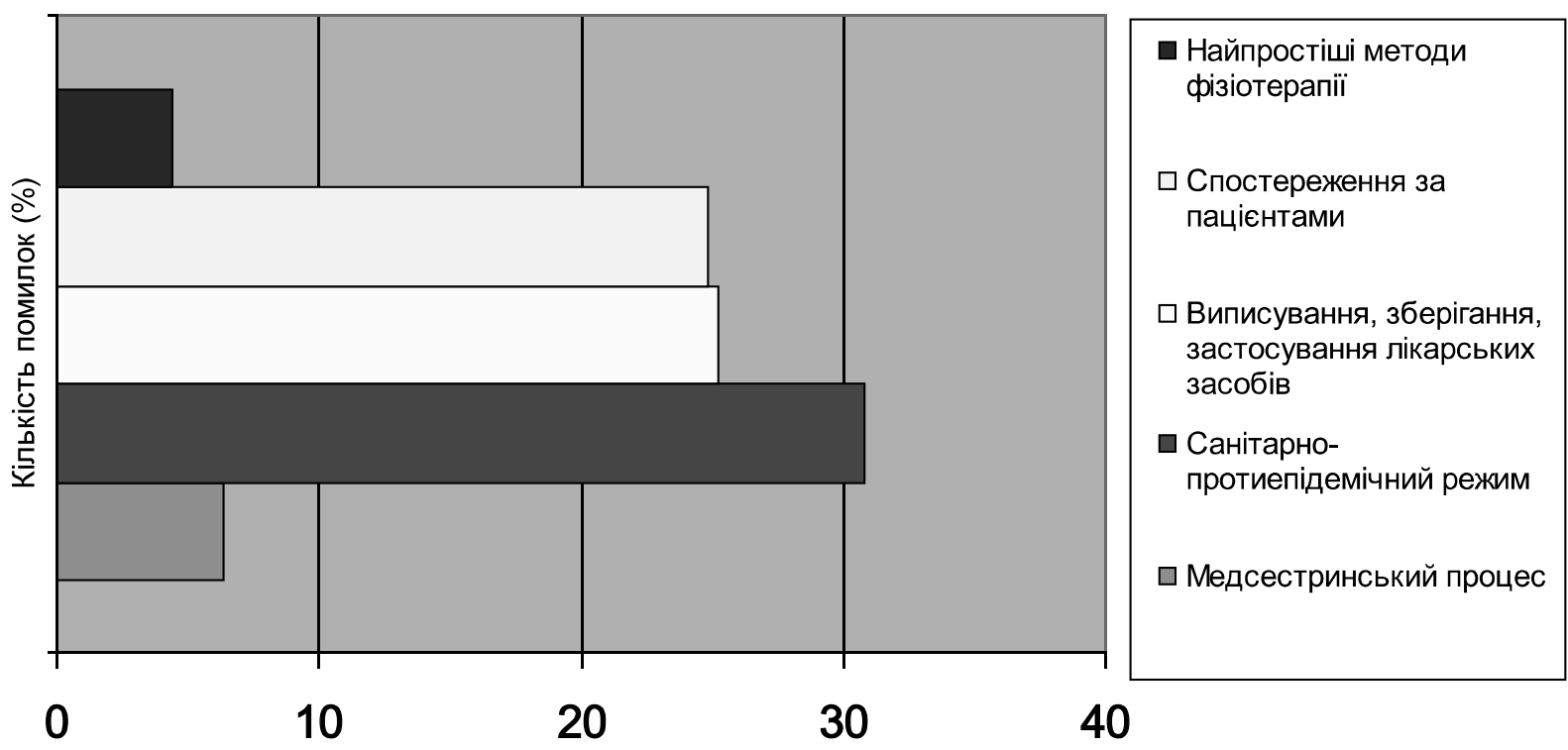

Рисунок 3. Кількість помилок у тестах працюючих медичних сестер відповідно до розділів.

оперативно приймати рішення, здатного не тільки виконувати призначення лікаря, а й забезпечувати індивідуальний догляд, співпрацювати з родичами і сім'ями пацієнтів [5, 6].

Впровадження принципів застосування інноваційних технологій у викладанні основ медсестринства на сучасному рівні вимагає від викладача використовувати різноманітні інноваційні технології, що забезпечують засвоєння, розуміння того, що лежить в основі догляду, який здійснюють не інтуїтивно, а продумано і має бути сформований підхід, розрахований на задоволення потреб і вирішення проблем хворої людини.

Ми вважаємо, що основноюумовою підготовки медичних сестер є максимальне зближення аудиторного навчання, позааудиторної роботи з практикою професійної діяльності. Тому при проведенні практичних занять ставимо за мету:

- прищепити зацікавленість до дисципліни «Основи медсестринства»;

- активізувати діяльність студента;
- встановити відносини творчої взаємодії між викладачем та студентами;

- впроваджувати методи проблемно-діалогічного навчання.

При викладанні предмета «Основи медсестринства» рекомендуємо широко використовувати технологію проблемного навчання з впровадженням таких активних форм, як практичне заняття-дискусія, заняття-практикум.

Перевагою творчої дискусії $\epsilon$ розвиток творчого мислення, надання можливості використовувати отримані знання в практичній діяльності, що допомагає студентам професійно засвоювати вміння і навички [7].

Для того, щоб досягти успіху в кінцевих результатах дискусії, активну роль відводять викладачу, який повинен заздалегідь визначити основні етапи розгляду проблеми, логічні зв'язки між основними елементами та сконструювати структурно-логічну схему.

Таким чином, під час проведення розбору клінічно-ситуаційної проблеми викладач виступає в 
ролі експерта, який контролює хід думок студентів і правильність зроблених студентами висновків, допомагає результативному визначенню проблем та їх вирішенню.

Використання таких занять-дискусій дає можливість застосовувати інтерактивні технології навчання (робота в малих групах, «мікрофон», «мозковий штурм» тощо). У наочності представленої студентам клінічної ситуації допомагає використання сучасних інформаційних технологій (комп'ютерна презентація, відеофільми, малюнки, світлини) [8].

Висновки. Враховуючи вищевикладене, постало питання про підвищення якості навчання на заняттях із предмета «Основи медсестринства». В зв'язку з цим, ми розробили рекомендації щодо впровадження в навчальний процес нових освітніх методик.

3 метою покращення якості викладання «Основ медсестринства» пропонуємо:

1. Заняття з розділу «Медсестринський процес» рекомендують проводити переважно в кабінетах до-

\section{СПИСОК ЛІТЕРАТУРИ}

1. Медсестринський процес. Основи сестринської справи та клінічного медсестринства // І. Я. Губенко, О. Т. Шевченко, Л. П. Бразалій, В. Г. Апшай. - К. : Здоров'я, 2001. - 208 c.

2. Медсестринський догляд за пацієнтом / І. Я. Губенко, О. Т. Шевченко, Л. П. Бразалій, В. Г. Апшай. - К. : Здоров'я, 2000. - 248 c.

3. Губенко І. Я. До питання поєднання медсестринської освіти та практики на основі запровадження медсестринського процесу / І. Я. Губенко, Л. П. Бразалій, О. Т. Шевченко // Медична освіта. - 2007. - № 4. - С. 18-24.

4. Про затвердження «Програми розвитку медсестринства України на 2005-2010 рр.» : наказ МОЗ України від 08.11.2005 р. № 585. клінічної практики шляхом моделювання клінічних ситуацій.

2. Заняття з розділу «Санітарно-протиепідемічний режим» рекомендують проводити у формі індивідуальних завдань, тестів, створення та розв'язання проблемних ситуацій та ділових ігор.

3. Заняття з розділу «Найпростіші методи фізіотерапії» рекомендують проводити переважно в кабінетах доклінічної практики на фантомах та тренажерах. Допускається відпрацювання маніпуляції студентами одне на одному в тому разі, якщо останні не супроводжуються ризиком для здоров'я або не зачіпають почуття власної гідності. Оснащення кабінетів доклінічної практики має відображати реальні умови та імітувати робоче місце медичної сестри.

4. Заняття з розділу «Спостереження за пацієнтами» рекомендують проводити в умовах відділень лікувально-профілактичних закладів під керівництвом викладача основ медсестринства.

5. Головащук Л. Самостійна робота - фактор активізації підготовки студентів - майбутніх медиків / Л. Головащук // Медична сестра. - 2008. - № 1. - С. 39-40.

6. Шатило В. Й. Наукові дослідження в медсестринстві як інструментудосконалення національної системи охорони здоров'я / В. Й. Шатило // Магістр медсестринства. - 2009. № 1 (2). - C. 5-6.

7. Літашова О. Застосування сучасних освітніх технологій / О. Літашова // Освіта. Технікуми і коледжі. - 2007. № 4 (19). - С. 26-27.

8. Смирнова 3. М. Основи сестринської справи. Посібник з медсестринського процесу / 3. М. Смирнова, 3. Б. Алтинбекова. - К. : Здоров'я. - 2002. - С. 258-264. 